\title{
Research and Development, Cash Flow, Agency and Governance: UK large companies
}

\section{Ciaran Driver}

and

Maria João Coelho Guedes ${ }^{\dagger}$

\begin{abstract}
This paper investigates the determinants of $R \& D$ expenditure using a sample of UK listed companies with the highest spend from 2000 to 2005. We investigate the effect of corporate governance and ownership on $R \& D$, using panel data. The results provide some evidence that more governance tends to depress $R \& D$ activity, a finding that is robust to whether a composite or disaggregated index of governance is used. One innovation of the paper is that we treat agency and finance effects interactively. The ownership stake of the CEO appears to be supportive for $R \& D$.
\end{abstract}

\footnotetext{
* Corresponding author Department of Financial and Management Studies, SOAS, University of London, Thornhaugh St, London WC1H 0XG; telephone (+44)20 7898 4993, email c.driver@ soas.ac.uk.

${ }^{\dagger}$ ISEG - Instituto Superior de Economia e Gestão, Universidade Técnica de Lisboa, R. do Quelhas 6 1200 Lisbon, Portugal, email mjguedes@iseg.utl.pt.
} 


\title{
RESEARCH AND DEVELOPMENT, CASH FLOW, AGENCY AND GOVERNANCE: UK LARGE COMPANIES
}

\begin{abstract}
This paper investigates the determinants of R\&D expenditure using a sample of UK listed companies with the highest spend from 2000 to 2005. We investigate the effect of corporate governance and ownership on $R \& D$, using panel data. The results provide some evidence that more governance tends to depress $R \& D$ activity, a finding that is robust to whether a composite or disaggregated index of governance is used. One innovation of the paper is that we treat agency and finance effects interactively. The ownership stake of the CEO appears to be supportive for $R \& D$.
\end{abstract}




\section{RESEARCH AND DEVELOPMENT, CASH FLOW, AGENCY AND GOVERNANCE: UK LARGE COMPANIES}

\section{INTRODUCTION}

The contribution of R\&D to economic growth has become a policy issue in recent years especially following the success of high-technology growth in the USA from the mid 1990s. Some have argued that this focus is exaggerated and that other channels such as the diffusion of general purpose technology are of equal if not greater importance (Hughes 2007). Nevertheless, R\&D contributes strongly to economic growth as attested to by individual studies (Wakelin 2001) and the digest of results in Greenhaugh and Rogers (2010). Most of these studies seem to confirm a private return over and above the likely cost of capital, though the time pattern appears not to be stable (Kafouros 2005; Lang 2009). At industry level, recent UK research shows a strong direct effect of R\&D on productivity growth for firms carrying out the research; spillovers also occur for non-performing R\&D players, but with the main gains accruing to other R\&D active firms, thus amplifying the gains from this form of innovation expenditure (O'Mahony and Vecchi 2009).

Given the importance of $R \& D$ for performance, the policy debate has turned to reasons why some firms or regions allocate more resources to it than others (Moncada-Paterno-Casada et al 2010). For some, the answer lies in finance constraints. R\&D is highly uncertain in terms of appropriability, subject to asymmetric information, intensive in sunk cost, and with a long pay-off; firms may therefore be driven to adopt short-run horizons to reassure arms-length investors, to the detriment of long-run R\&D projects, which arguably require patient capital, close oversight and engaged investors. Others, however, argue that the provision of finance is best assured by institutional forms that permit liquidity and ensure exit options for investors. The debate is mirrored in the institutional labour market literature where on the one hand, tenure and tolerance of failure is said to favour risk-taking by employees while on the other the need for creative destruction and rapid reallocation in some industries appears to favour top-down control. 
These issues form a set of debates that go under the rubric of corporate governance. Given the international variety in the institutions of governance there has been a wide-ranging debate as to whether innovation profiles in different regions such as the UK, US, mainland Europe and Japan can be explained in these terms - the varieties of capitalism debate (Hall and Soskice eds 2001; Hancke 2009). There is some controversy over whether a mapping exists from distinct institutional forms of capitalism to comparative advantage for particular sectors or technologies (Lundval 2002; Taylor 2004; Tylecote and Ramirez 2006; Crouch and Voelzkow 2009; Casper 2009). Whatever the outcome of this controversy, there is increasing interest in the role of corporate governance in technology choices. The innovation literature is accumulating studies in respect of ownership structure (Calderini et al 2003; Munari et al 2010); the role of short termism and finance (Hall 2002, O'Sullivan 2005, Demirag and Doi 2007); or of board composition and design (Munari and Sobrero 2003; Kor 2006). Indeed, Tylecote (2007) claims that corporate governance is now central to determining "firms' efforts in innovation and technological change" (p.1476). That is the main idea that we wish to explore further in this paper, where our interest is in estimating the direction and significance of any impact. However, our focus will be narrower and more specific than in some previous work. In particular, we look at the R\&D expenditure by large corporations incorporated and listed in the UK.

\section{CORPORATE GOVERNANCE AND FINANCE: EFFECTS ON INNOVATION}

At least from the 1970s, corporate governance of shareholder economies has been viewed narrowly, as a system of control in which shareholder interests are dominant. Earlier there had been a loose consensus that managers should (or did) exercise autonomous control of the firm of the firm (managerial capitalism). Shareholder orientation of firms gained ground first in the United States where international competition caused investors to seek higher returns and more accountability from executive management. The theoretical framework underpinning this approach is that of "principal-agent" where the principal normally refers to the owner or investor and the agent to the manager or worker who is hired under a fully specified or complete contract. 
The challenge of principal agent theory is to design a system that aligns the interests of owners and managers, since the owner cannot always infer or observe effort (Eisenhardt 1989). Corporate governance is an institutional form that addresses this problem; the costs incurred in setting up these governance mechanisms form part of what are known as agency costs. These include monitoring arrangements or more usually an incentive system to persuade managers to take risk. In recent years, a number of corporate governance codes, national and transnational, have been agreed that set out principles or rules to safeguard the interests of owners. These include transparency and oversight through good design of the board of directors, and approaches to incentivising senior management (Higgs 2003, OECD 2004). It is now common for companies to be assessed using a corporate governance index that records the extent of compliance with such codes (Gompers et al 2003; Higgs 2003).

The application of a governance code is expected to have virtuous effects that operate through two channels. First, it may reduce the cost of funds (cost of capital) for long-run and uncertain projects such as capital and innovation investment. Second, it may directly affect decision-making in a way that reduces self-serving behaviour by managers. In this article, in keeping with much of the literature, we refer to these principal-agent mechanisms as "good governance", but without necessarily ascribing to that term any approbation. A third channel of influence from governance to R\&D contradicts the supposed benefits of close alignment of manager and owner interests. In particular, some observers see a danger in "over-monitoring" that reduces managerial autonomy (Baysinger 1991, Aghion and Tirole 1997). It is argued that innovation may suffer where owners are removed from the sources of technical knowledge (Lazonick 2008). Furthermore, the interests of owners may conflict with innovation investments when owners are disposed to favour liquid assets in preference to long-term sunk and uncertain ones. Ultimately it is an empirical matter whether governance supports R\&D expenditure (through transparency etc) or depresses it (through reduction of autonomy and excessive caution). 
The above is necessarily a very compressed view of the mechanisms by which governance affects innovation. ${ }^{3}$ Nevertheless it allows a simple framework that can inform the empirical work in this article. We aim to test the principal agent views against the alternative idea that many of the mechanisms of "good government" may have perverse consequences for innovation. To that end we first test the proposition that governance encourages innovation by improving the terms of finance or the barriers to raising finance. Financial investors do not always know or care which specific projects within a company that money is being raised for. Their concern is whether governance procedures are in place to protect their investments. Thus insofar as governance encourages R\&D through reducing finance constraints, we expect that the governance variable that is relevant is a general, or aggregated, index of governance that financial investors tend to monitor. We will construct such as index (CG) by reference to the literature in this area.

The second channel of influence from governance to innovation is also set within the principal agent framework and concerns the direct effect of more transparency, better monitoring or more aligned incentives on the management of innovation. Our focus here will be on the elements of governance most likely to address the specific need to generate appropriate levels of innovation investment. To this end we disaggregate the index to try to understand the specific influence of its components.

\subsection{The Institutional Context Of Corporate Governance In The UK.}

Firms listed in the United Kingdom operate under a different corporate governance framework than either the types typical in mainland Europe and Japan, or the United States. The latter difference is not always noted because commentators often group together countries termed "liberal market economies" (LMEs) where firms tend to be listed so that a thick market exists for shares and whole companies. These are contrasted with "coordinated market economies" (CMEs) characterised more by

\footnotetext{
${ }^{3}$ Other important issues concern the role of property rights in inducing effort and commitment (Aiguilera and Jackson 2010). Two broad-reaching studies of corporate governance and its effects on innovation are Belloc (forthcoming 2012) and Driver (forthcoming 2012). Belloc identifies three sub literatures dealing with the links between innovation and governance: principal-agent, "incomplete contracting" and "organisational control theory". He relates these to three discourses in the literature on the effects of ownership, financial systems, and human resource management so as to identify a large number of competing hypotheses and corresponding evidence. Driver classifies the literature into six theories : principal agent; transactions cost; resource-based theory; property rights; adaptation; and varieties of capitalism discussing both the main hypotheses, their implications for innovation, and the empirical evidence.
} 
block-holdings by other firms, banks or families and where it is more difficult to buy control of firms. The dichotomy refers not just to systems of corporate governance but to a co-evolved system of , finance, firm-level incentives, industrial relations, education and inter-firm collaboration. Under these conditions, concentrated holdings, typical of CMEs, are said to permit a longer-term planning horizon, while longer tenures for employees underpin investment in training (Hall and Soskice 2001). This simple dichotomy between LMEs and CMEs is not without merit. It can be used to illustrate how countries such as the UK differ radically from others such as Germany on issues such as intra-industry cooperation in innovation (Love and Roper 2001). But the situation is more complex because there are also serious differences between countries within each camp and in particular within the two most important LMEs, the UK and the US (Tylecote and Ramirez (2006); Mallin, 2007; Bruner 2010). Two such distinctions will be identified here because they have a bearing on innovation. First, the United States, having flirted with a system that permitted easy hostile takeover in the 1980s recast that approach that by permitting takeover defences in most states from the end of that decade (Bertrand and Mullainathan 2003; Tylecote and Visintin 2008). By contrast in the United Kingdom it is harder for management to fend off a hostile bid. This has implications for the horizon length with which UK managers plan for the future. A second difference is the much greater size of the US financial market relative to the UK which permits economies of scale in financial monitoring of technology. Financial analysits in the US have greater access to more detailed information on technological firms than is the case in the UK (Tylecote 2007). This issue has been repeatedly identified as a block on long-term provision of finance for R\&D. ${ }^{4}$

The lack of information matters especially in industries where external finance is needed to fund future growth. If managers, with their superior inside information, are prevented by stockmarket pressure from acting autonomously, it is necessary for the investors themselves or their board representatives to make informed judgments. But the ownership structure in Britain militates against this, at least in its present form, since voting blocks rarely exceed $10 \%$ of shares and there is thus a "free-rider" problem as who would bear the cost of close oversight and intervention. During the

\footnotetext{
${ }^{4}$ Early mentions of this problem include the Innovation Advisory Report (1990). A systematic account of the issue is contained in Tylecote and Visintin (2008).
} 
sample period, UK insurance and pension firms owned almost exactly one third of the shares of UK listed companies. A further third was owned by foreign interests with the remainder split between individuals, non-financial companies, banks, investment trusts, hedge funds and public bodies. ${ }^{5}$ Exceptionally, with large UK listed companies, a hedge fund or sovereign wealth fund may intervene pro-actively to change strategy in companies that they part own. But the big players such as pension funds and insurance funds, despite government entreaties, have mostly resisted pressure to engage in this process and prefer to maintain an arms-length relationship.

Thus, the example of the UK provides an interesting laboratory for examining the influence of corporate governance on innovation. Of the liberal market economies it comes close to being a polar case where liquidity matters for investors rather than long-term commitment. As noted in Brunner (2010), “...the UK corporate governance system is substantially more compatible with theories emphasizing shareholders' interests that the US corporate governance system is." (P.610). Thus, UK managers have to make innovation decisions knowing that their company can rapidly change ownership and knowing that investors are likely to respond to disappointing results by a quick sale rather than informed pressure for a change of strategy. The question we explore is whether the formalisation of shareholder orientation in the UK corporate governance code - that was increasingly accepted by all major companies during our sample period - had a general effect of encouraging or discouraging investment in R\&D.

\subsection{Testing For The Effects Of Governance On R\&D}

Our intention in the paper is to test the channels of influence from corporate governance to R\&D spending. The elements of good governance consist of measures to align the interests of owners and managers, viz: board independence from executive management, transparency and ease of achieving oversight, and incentives. (Higgs 2003).

\footnotetext{
${ }^{5}$ The figures are from Mallen (2007) citing ONS data for 2004. These ONS data have recently been criticised for inadequate sampling methods, but apart perhaps from overseas holdings, any revisions are unlikely to affect the general pattern noted above.
} 
Irrespective of whether governance procedures have these hypothesised effects, it is undeniable that company boards have become obliged to pay attention to such issues. As noted by Lysandrou and Parker (2011), the practice of collapsing the multiple dimensions of corporate governance into a summary statistic of an optimal structure of governance is now accepted by regulatory authorities as well as asset managers which explains "why corporations are under pressure to conform to that optimal structure" (p.2). We term this process the conformity channel of influence from governance to $R \& D$ because it is concerned with relieving finance constraints through making companies acceptable to investors (Tirole 2006; Hall and Lerner 2010).

We are also interested in isolating any direct effect of governance changes on R\&D that may arise from specific individual features of governance rather than simply from the extent of compliance with the standard checklist. The argument here is that some specific features of governance may be conducive to innovation, even if the overall index is not. We term this process the direct effects channel of influence and we investigate it by disaggregating the overall indicator of governance. Of course, just as the overall index may result in positive or negative effects on $R \& D$, the same may be true of some of its components. Again this is largely an empirical matter.

In the remainder of this paper we set up a specification and report empirical results on the link between governance and R\&D. Section 3 outlines the theoretical foundation of R\&D investment and shows how governance may be expected to modify the basic model by setting out a number of hypotheses. A number of hypotheses are presented. Section 4 details the specification used in testing these hypotheses, along with brief accounts of existing evidence. The sample and data sources are then outlined in Section 5 , This is followed by a discussion of the results in Section 6. Concluding comments follow in Section 7. 


\section{THEORIES OF R\&D INVESTMENT}

A good general understanding of the drivers of firm-level $R \& D$ expenditure has been available for some time (Saviotti 1987; Cohen 1995; Crepon et al 1998) but further progress has been slow; studies of aggregate $R \& D$ expenditure and its determinants are now relatively rare in the field of innovation studies. In part this may be explained by disagreement over its adequacy as a measure of innovation, or even of innovation effort (Pavitt 2005). Some estimates suggest that in the UK, R\&D accounts for only about half of all innovation inputs (Bulli 2008; Roper et al 2008). Even so this is still substantial and it of some concern that variation in R\&D intensity of UK-owned firms has not yet been well explained (Bulli 2008;Rogers 2006).

Given that questions of appropriability and uncertainty are significant features of $R \& D$ it is only natural to consider finance as a possible constraint on R\&D and to consider whether routines of good governance could lessen such constraints and indeed ameliorate any general agency concerns that might affect the R\&D decision. In recent papers, it has been suggested that further progress may depend on integrating the theory of R\&D investment with models of agency and financial constraints (Hall 2002; O'Sullivan 2005; Lhuillery 2011).

$R \& D$ is characterised by specific features. First, assets are intangible (and thus largely sunk or irreversible); second, its gains are difficult to appropriate in full unless protection is available through patents, secrecy, or unique complementary assets; and third, its cash flows are both long-term and unusually risky. Nevertheless, although $R \& D$ is a distinct activity it has similarities with capital investment and may thus be modelled similarly. For example, although fixed investment is surely tangible it is also highly irreversible at least in manufacturing sector (Asplund 2000). In regard to spillover effects, these are not confined to technology given that market externalities are often present (Porter 1985). ${ }^{6}$ Nor is risk uniquely related to research intensity, as may be observed by any casual observation of high Beta stocks. Many other claims for the specificity of $R \& D$ such as its strategic importance and its two-faced role in being both performative and informative also apply to any tangible investment that offers option value (Cohen and Levinthal 1989). Indeed the

\footnotetext{
${ }^{6}$ Nor are the methods of appropriating profits from innovation so different as for other investments. Cohen et al (2000) confirm that secrecy, lead time and complementary activities are key in most industries.
} 
notion that R\&D capital stock acts as a sponge for ideas that can be released when market conditions are ripe has a close correspondence to the idea of excess capacity as a strategic reserve for companies. It thus seems reasonable to argue that the standard theory of investment may provide a good starting point for R\&D estimation, as long as the model incorporates irreversibility and uncertainty (Mairesse et al 1999; Bond et al 2003). Indeed the somewhat surprising conclusion of this literature is that differences in the estimated structural relationships - apart from adjustment speeds - are larger across countries than across classes of investment.

The modern theory of investment under uncertainty is a development of Tobin's Qtheory where a signal for profitable investment is given when the marginal addition to firm value accruing from the investment exceeds the incremental cost (Summers 1981). Under restrictive assumptions, this is equivalent to a modified accelerator model with a cyclical term, driven by sales (Driver et al 2005). The dependence of R\&D on sales corresponds to the empirical literature (Saviotti 1987;Stephan 2004). Other industry-level evidence for the UK confirms that output or value added is the main explanatory variable for R\&D (Vecchi et al 2007; Becker and Hall 2009).

$R \& D$ investments involve uncertainty and irreversibility, a combination that is often analysed using a real options framework. The option to wait (where uncertainty and fixed cost feature) leads to a higher hurdle rate for R\&D (Dixit and Pindyck 1993; Mcdonald 1998; Chirinko and Schaller 2009). But the option to follow on (that characterizes some R\&D sectors) reverses this conclusion, as does situations where quick expansion of supply is difficult following a demand shock (Smit and Trigeorgis 2004; Driver et al 2008). For technologically advanced investments and R\&D expenditure, both optionalities (irreversibility and expandability) are likely to come into play and since the conditions in which either one might dominate are hard to specify, the implications for a model of R\&D are unclear. .

Nevertheless, the very fact that private information is important to assess the hurdle rate for R\&D gives some fresh insight into how to model it. Real options analysis complicates the signal for R\&D investment not just for the econometrician but also for those charged with assessing, monitoring and overseeing such investments i.e. 
the board of directors, analysts, rating agencies, credit providers and ultimately the investors themselves. In effect the complication produced by real options analysis creates an information asymmetry and information advantage for managers vis a vis the Board and magnifies any agencies problems that normally characterise long-run corporate decision-making. Real options theory thus justifies an investigation of the effects of governance procedures directed at resolving principal agency issues. If asymmetric information between managers and investors is severe, as in many R\&D intensive businesses, investors will tend to rely on general assurances that companies are complying with good practice. Thus the financial conformity hypothesis - that investors pay attention to general corporate governance indices will be important to test.

\subsection{Setting Out The Hypotheses}

3.1.1 The conformity channel. Before identifying the hypotheses, we need first to specifiy the directional effect of the conformity channel of influence that relates to how governance reassures investors. We argue below that enhanced governance will, according to the standard principal agency view, increase R\&D because investors will be assured that managers are not shirking. Since R\&D usually has lengthy pay-back periods, involves the uncertain role of absorptive capacity building, and is characterised by high idiosyncratic risk, there is an a-priori expectation of underinvestment by managers that governance needs to assess (Eisenhardt 1998; Hall 1990; Cheng 2004). This is particularly so where managers are highly mobile or have short tenures (Palley 1997), or where earnings management is practised (Bushee 1998). ${ }^{7}$ Our maintained assumption therefore is that R\&D is characterised by underinvestment to begin with, implying a positive relationship between governance variables and R\&D activity. We therefore test:

H1: Greater levels of governance induce more $R \& D$ spending.

As noted in Hall (2002), existing research is "fairly silent on the magnitude of these [agency] effects" (p.39) and by implication is equally silent on the power of any corresponding governance solutions. It is not even a priori clear that there will always

\footnotetext{
${ }^{7}$ R\&D managers do appear to have short tenures (Lerner and Wulf 2006). Empire building with R\&D might conceivably be explained by entrenchment where managers are specialised but it seems unlikely that R\&D decision-making is decentralised to the level of specialised managers and in any case managers may more easily defend themselves by expenditure on marketing or diversification (Krafft and Ravix 2005, Kor 2006).
} 
be a positive effect of governance on R\&D. The possibility of perverse effect of "good governance" on uncertain investments through discouraging autonomy has also been noted in the literature (Baysinger et al 1991; Burkart. et al 1997; Lazonick 2008). We are thus led to consider an alternative hypothesis against which $\mathrm{H} 1$ may be compared:

\section{HA1: Greater levels of governance induce less R\&D spending.}

Next, we consider a different way of testing the conformity channel by looking for a possible interaction effect between the cash flow (finance constraint) and the corporate governance index (CG). Under asymmetric information between managers and investors, R\&D projects will primarily be financed from internal funds according to the "pecking order theory" (Frank and Goyal 2008). Where there are more profitable opportunities than can be funded internally, this may lead to a finance constraint, indicating a potential positive effect of free cash flow on R\&D expenditure.

Arguably, the effect of incidence of financial constraint would disappear in wellgoverned firms, since investors would be reassured, thus attenuating the "lemons" problem (Stein 2003). Figure 1 shows a simple demand and supply diagram of funds for R\&D where a flat portion of the supply curve turns upwards at the point where external funds are called upon. If the demand for R\&D funds intersects the rising portion of the supply curve, the return to $R \& D$ will have to be higher to justify the cost. Governance can have several effects in this model. It can translate the demand curve to the left or right depending on whether it depresses or encourages $R \& D$ directly. At the same time, in relation to the conformity channel, good governance can flatten the supply curve if information and transparency reassure investors. To our knowledge this interactive effect of governance and cash flow on R\&D has not previously been investigated in R\&D investment studies. However, the interpretation of financial constraints in investment and R\&D studies has continued to be a source of controversy in the literature. ${ }^{8}$. We thus test the hypothesis:

\footnotetext{
${ }^{8}$ The evidence in favour of a cash flow effect for R\&D is mixed (Bond et al 2003). Previous results supportive of a link include Hall (1992; 1999); Himmelberg and Peterson (1994) and Mulkay et al (2001). Cincera and Ravet (2010) suggest that financing constraints on R\&D have appeared in Europe, but not the US since 2000, whereas earlier work by Hall (2002) suggested a higher cash flow coefficient for the US and UK than elsewhere. A related finding in Bond et al (2003) suggests that cash flow is important for the decision to do R\&D but not its intensity. Malmberg (2008) finds significance for cash flow on Swedish pharmaceutical company R\&D at industry and firm levels using
} 
H2: Greater levels of governance operate to reduce any financial constraints for $R \& D$ intensive firms

3.1.2 The direct channel. So far we have been concerned with the conformity channel according to which the importance of governance is to give assurance to investors through compliance with a generally accepted code of practice. This may not be the only channel through which governance operates, Even within a standard principal agent view it is possible to regard some aspect of governance principles as more relevant or sensible than others. Indeed the available literature indicates considerable heterogeneity in results. Given these conflicting findings, we test individually the sub-components of the CG index, specifically:

H3 Individual components of a general government index contribute different directional effects to the index itself.

We also address in this paper the influence of ownership form on $R \& D$, a feature related to, but somewhat distinct from governance. The concentration of shares owned by investors and who owns them are issues that can affect the ease with which direct oversight of managers can be coordinated. Block ownership (usually defined as a holding greater than $5 \%$ ) is one attribute that may encourage more oversight (Bushee 1998). The same may be true of some types of institutional ownership. Finally, ownership by executive management such as the CEO may be of particular significance since it not only gives management a stake in the company but allows the arguably better informed members of the board to display more independence in relation to other members. Our final hypothesis is thus: H4 Greater Managerial Ownership and Institutional Ownership induce more R\&D spending.

a two year lag and a long data series over four decades. Ughetto (2008) finds an effect for Italian SMEs; Canepa and Stoneman (2008) report a similar effect for UK firms for a broader category of innovation. Hyytinen and Toivanen (2005) identify a financial constraint by investigating the effect of R\&D subsidies. However Vecchi et al (2007) find no evidence for interest rates or current profits in their industry-based analysis of the UK. Rogers (2006) infers a lack of financing constraints for large $R \& D$ spenders in the UK on the basis of comparative international R\&D productivity. Brown et al (2009) find no evidence for financial constraints for large hi-tech firms in the US, only for younger growth firms. 


\section{MODEL SPECIFICATION}

Following the general discussion of R\&D determinants in the previous section, we embed a target ratio for R\&D-to-sales intensity in an adjustment model with dynamic effects that capture the error-correction path of R\&D expenditure. Such an approach has typically been employed in investment studies (Mairesse et al 1999; Bond and Van Reenan 2007) and has also been used in studies of R\&D (Bond et al 2003; Becker and Hall 2009). It has the advantage of making it more likely that the dependent variable is stationary, as investment is normally thought of as integrated of order one. It has the further advantage that by modelling explicitly the cyclical adjustment, it prevents this from being confounded with cash flow (Harhoff 1998). ${ }^{9}$

Writing $R D I_{i, t}$ for RDI intensity measured as the ratio of $\mathrm{R} \& D$ to sales for firm $i$ at time $t$

$\Delta \ln (R D I)_{i, t}=\alpha_{0}+\beta_{1} \Delta \ln (R D I)_{i, t-1}+\beta_{2} \ln (R D I)_{i, t-1}+\mathrm{u}_{\mathrm{i}}+\mathrm{e}_{\mathrm{it}}$

The basic model is supplemented by a number of variables. In regard to size of the firm itself, it has been argued since Schumpeter (1942) that large firms may have several advantages that encourage R\&D spending including better access to capital, greater economies of scale and more complementarities. Set against this, large firms may encounter loss of managerial control in resource allocation and they need to rely on lower power incentives (Cohen 1995). Hence the role of size is ambiguous and may be more relevant to the decision to do R\&D rather than its intensity (Bulli 2008). Nevertheless, size is also associated with process innovation according to the innovation life cycle hypothesis and such innovation may be more R\&D intensive (Reichstein and Salter 2006). Size is sometimes interpreted as a proxy for market power or an inverse indicator of product market competition, but again the theoretical impact on innovation impact is ambiguous (Aghion et al 2005; Vecchi et al 2007) There is also an argument that size proxies for indicators of absorptive capacity and

\footnotetext{
${ }^{9}$ We regard the Euler framework as unsuitable for the R\&D context; the adjustment costs are discontinuous in the presence of real options that are likely to characterise irreversible investment and we do not have good firm-level data to model these expected disequilibria.
} 
the ability to enter into collaborative arrangements. We include size in our regressor set, mindful of these ambiguities.

Public subsidies may also be argued to affect the private expenditure of R\&D. One issue is whether direct grants crowd-out (or crowd-in) private expenditure either at the level of the firm or economy. The study by David et al (2001) and the meta-study by Garcia-Quevedo (2004) were inconclusive. Guellec and Van Pottelsberghe de la Potterie (2003) found positive rather than negative effects except in the case of defence subsidies for 17 OECD countries; Gonzalez and Pazo (2008) found no indication of crowding out in the case of Spanish manufacturing firms. In our specification, only time-varying effects need to be included which is of interest because temporary subsidies tend to be ineffective. ${ }^{10}$ In Section 6.1 we report a split sample excluding defence-related firms who are most likely to receive subsidies.

Clearly there are many issues that influence $R \& D$ that are not expressed in (1) as they are subsumed in the fixed effects $u_{i}$ term that includes all non-time varying determinants, such as the general appropriability conditions and technological opportunities. ${ }^{11}$ A reasonable question to ask is whether, in any panel of high technology firms, these effects can really be taken as fixed given that the boundary of the firm may alter over time. Our answer here is that the time frame is just six years and that we later report (Section 6.1) split sample results which seek to identify if the character of the results change by excluding firms most subject to these criticisms.

\footnotetext{
${ }^{10}$ Another issue relates to the tax credits for R\&D announced for large firms in 2001. The credit operates in respect of incremental R\&D performed in the previous two years. As the policy extension was well telegraphed to companies it may be expected to have had an effect over our entire sample period, though it corresponds to only a fraction of a percent of the cost of capital Any effect should not vary much across large firms because they are unlikely to be tax-exhausted (and because it is an incremental rather than a volume measure). The dynamic effects are, however, unclear as the incremental $R \& D$ for which credits are paid raise the threshold for subsequent claims (Bloom et al 2001).Furthermore, the credit applies only to UK-performed R\&D so its incidence is difficult to track. ${ }^{11}$ Crepon et al (1998) found that market share variables displaced size in equations explaining the R\&D stock, while variables such as diversification, and demand-pull and technology -push dummies were sometimes significant. The latter were obtained from innovation surveys which we are unable to use as our sample concerns global activity.
} 


\subsection{Adapting The Basic Model To Test Hypotheses}

Under $\mathrm{H} 1$ we expect increased governance to result in more R\&D. ${ }^{12}$ Accordingly, we include in the specification a standard index of good governance (CG) to test its effect on R\&D intensity, an index of financial constraint (cash flow CF) and also a control for size (SZ). We do not expect a levels effect for the cash flow variable as it represents a constraint on adjustment. This results in equation (2).

$$
\begin{aligned}
& \Delta \ln (R D I)_{i, t}=\alpha_{0}+\beta_{1} \Delta \ln (R D I)_{i, t-1}+\beta_{2} \ln (R D I)_{i, t-1}+\beta_{3} \ln (S Z)_{i, t}+\beta_{4} \Delta \mathrm{CG}_{\mathrm{i}, \mathrm{t}}+ \\
& \beta_{5} \mathrm{CG}_{\mathrm{i}, \mathrm{t}-1}+\beta_{6} \Delta \operatorname{lnCF}_{\mathrm{i}, \mathrm{t}-1}+\mathrm{u}_{\mathrm{i}}+\mathrm{e}_{\mathrm{it}}
\end{aligned}
$$

Hypotheses $\mathrm{H} 2, \mathrm{H} 3$ and $\mathrm{H} 4$ require slight modifications to (2) that amount to the inclusion of an interaction term between $\mathrm{CG}$ and $\triangle \mathrm{CF}(\mathrm{H} 2)$; the disaggregation of $\mathrm{CG}$ $(\mathrm{H} 3)$ and the addition of ownership variables $(\mathrm{H} 4)$.

\subsection{Definition Of The Corporate Governance Index (CG)}

As the contribution of corporate governance is at the heart of this paper we indicate here how the index $C G$ has been constructed. This follows the conventional approach (Gompers 2003; Black et al 2006) in that the index comprises both structure and procedures of the board of directors, and the manner of executive compensation.

Boards are argued to be more effective if they are small, have separate people as CEO and Chair, and have a degree of independence from executive management. We include an indicator of each of these in our index with the added feature that in regard to independence we distinguish bare compliance - which is equality of executives and non-executive (independent) members - from a more pronounced independence stance where the independents have a strict majority. We do this because there is clustering by firms at the conventional level of $50 \%$ independents.

The CG index comprises six components (four board variables and two for compensation) as follows:

\footnotetext{
${ }^{12}$ The maintained hypothesis here is that managers are overcautious or myopic in respect of $R \& D$ (Hall 1990). Hall and Lerner (2010) cite evidence that anti-takeover measures that increase managerial security either increase or do not decrease R\&D.
} 
Board size: dummy variable $=1$ if board size $<12$

Separation of powers: dummy variable $=1$ if CEO and Chair of Board are not the same person.

Observance of Higgs (2003) code of practice: Dummy variable $=1$ if at least $50 \%$ independent or non-executive.

Independent Control: dummy variable $=1$ if a clear majority of directors are independent or non-executive.

The index contains two other dummy variables for compensation where the intention is to identify different types of high-powered compensation in relation to basic pay, with the most high-powered incentive being payment in stock and options whose value is generally contingent on future firm performance.

Bonus: Dummy variable $=1$ if bonus component in total compensation $>20 \%$

Stock \& Options: Dummy variable $=1$ if stock and options component in total compensation $>30 \%$

Note: The above critical values for compensation correspond to the average percentages for large UK companies reported in Conyon et al (2009).

The CG index is then formed as a simple sum of zero-one dummies over the six components of the above list. Our index is a stripped down version of some others in the literature such as Black et al (2006) given that our sample of large firms displays less heterogeneity than in many studies so that all the firms in our sample have for example, a remuneration and an auditing committee. The index is constructed separately from ownership variables that are introduced when discussing the results for Hypothesis $\mathrm{H} 4$ in Section 6.4 .

\subsection{Previous Results Relating R\&D To Governance And Ownership}

For managerial incentives Wu and Tu (2007) using Computstat data for large research intensive firms find that CEOs high powered compensation can increase $R \& D$ under high growth or with high slack, but that does not extend to other types of incentive pay. This limited result is consistent with Eng and Shackell (2001) and Devers et al (2000) who find an effect on CEO risk-taking but only for some forms of equity-based pay. Lhuilery (2011) using a large sample of French firms does not identify a separate compensation effect on $R \& D$. 
In relation to independents on the board of directors, much of the evidence does not support a positive link with R\&D. Hill and Snell (1988) and Baysinger et al (1991) using Fortune 500 samples find negative relationships, while David et al (2001) finds no significant moderating influence of outsider executives on a positive role for institutional investors. Kor (2006 ) in a US study finds no effect for outsiders on R\&D intensity or in countering the tendency of long-tenured management teams to avoid investment risk for uncertain long-term projects. Hoskisson et al (2002) finds that outsiders on the board is associated with acquisitions rather than internal innovation. Lhuillery (2011) finds some support for a positive effect of governance principles on $R \& D$ intensity, though not for board composition. The same is true of Lacetera (2001) for a study of the US pharmaceutical industry . Other issues such as board size have found more consistent results with a presumption in favour of efficiency for smaller boards, often with an upper limit of 12 being suggested following the classic US study by Yermack (1996). Guest (2009) confirms that large UK boards suffer from coordination difficulties but his results suggest that this effect is reduced for firms with high R\&D intensity, while Cheng (2008) finds a positive effect on R\&D spending from larger boards in US technology firms.

The literature on ownership also contains conflicting results. There is some evidence of a positive effect on R\&D of concentrated or institutional holdings (Hill and Snell 1988; Smith et al 2001; Lee and O'Neill 2003; Munari and Sobrero 2003). Aghion et al (2009) find a small and fairly weak effect of institutional ownership on R\&D but they argue that the main effect of governance is on the productivity of R\&D. The role of CEO ownership is also controversial with some claiming it has an important incentive effect, or acts as reassurance for investors, while others argue the reverse - that it acts as as form of entrenchment. Of course, since entrenchment is often indistinguishable from autonomy there is yet another dimension to consider, raising the possibility of a non-linear inverted U-share relationship between CEO ownership and R\&D spending (Ghosh et al 2007).

\section{SAMPLE AND AND DATA}

Governance operates at the level of the jurisdiction of national corporate law and stock exchange listing so our interest is in the total expenditure of UK-based 
companies, not in expenditure on UK-performed R\&D. The reason for limiting our sample by size and jurisdiction is partly one of data access. Data is required for each firm not only for the standard determinants of innovation expenditure but also for a range of governance characteristics; this is time consuming and expensive to collect and each data-point needs to be checked carefully for anomalies. The restriction to UK-listed firms confines the analysis to one "variety of capitalism" though it should be stressed that large UK firms are international in terms of reach and perform $R \& D$ increasingly abroad (BERR 2008). Additionally, this narrow focus simplifies the interpretation of the analysis. Previous work has shown for example that different jurisdictions have oppositely signed effects of governance variables on innovation, as with the role of institutional ownership on innovation in the USA versus Japan (Lee and O'Neill 2003) or Europe versus the UK (Munari et al 2010): the implication is that corporate governance works differently in different environments. In our view the corporate governance framework that affects important decisions such as R\&D is that corresponding to where the firm is incorporated; that is after all the level of enforcement through stock exchanges and national legislation. (Windsor 2009). There is of course some variety in the degree of autonomy of foreign subsidiaries and there is a literature on how the exploitation of local country-based resources can fit with centralised power and decision-making (Birkinshaw 2001). One detailed case study of a UK-based multinational and its foreign subsidiaries showed that "only marketing, distribution and after-sales service" tends to be organised regionally with $R \& D$ and capital investment centralised (Krisetensen and Zeitlin 2005). The reason was attributable to its stock-based financing mode: "Nothing could be more important from the headquarters perspective...than to ensure that the City received a single coherent story..." (p.141). While there may be exceptions to this pattern, for shareholder economies at least, it seems likely that major strategic decisions are centralised, given the need to offer a disciplined narrative that caters to investors in its financial base. This conclusion is also supported by survey evidence on whether global firms with multiple technologies centralise their R\&D (EIRMA 2000).

Our initial sample comprised the top 100 UK manufacturing and service (excluding financial) firms, with the highest averaged R\&D expenditure in the period 2000-2005. We had to exclude some firms because of missing values for R\&D expenditure. For 
example, some firms showed a change from zero $R \& D$ expenditure to a positive expenditure in the course of a single year. This might be because the firm had not performed R\&D for some time; however, this is unlikely based on the fact that the sample includes the top R\&D spenders, and means that zero values are likely to result from non-recording. In line with Bond et al (2003), we excluded the set of observations with missing data from the sample.

Our final sample consists of an unbalanced panel of 91 firms and 546 year observations, for the top R\&D spenders in the UK. Manufacturing firms predominate, with some $70 \%$ of firms. The predominant sectors are Electronic and Electric Equipment with 12 firms (about 13\% of the sample) ,Software and Computers with 13 firms and Pharmaceuticals with 8 firms. The sample accounts for about $76 \%$ of total R\&D expenditure by UK business (BERD).

There are some positive arguments in favour of our sample restriction. The largefirms that we analyse not only perform the vast bulk of total R\&D but have also been subject to most scrutiny and pressure in terms of their governance procedures (Higgs 2003). While there are other important R\&D policy issues in regard to small firms' participation and sustained efforts in innovation, we believe that the governance influence will be best captured in our restricted sample if it is indeed of importance. Given our focus on top spenders, we do not, in this paper, deal with the decision of whether or not a firm performs R\&D in the first place. Thus our results are to be interpreted as conditional on the firm being $R \& D$ active.

Data on R\&D, sales and cashflow were downloaded from Datastream. ${ }^{13}$ R\&D intensity is calculated as the ratio of R\&D to Sales. Figure 2 shows the mean R\&D intensity over the sample indicating that the period contains substantial time variation. Size is measured by number of employees. The Cash Flow variable is based on the Datastream data extracted from company annual reports, where it is defined as the value of net income, plus amortization and/or depreciation, less change in working capital, less capital expenditure. However, because R\&D

\footnotetext{
${ }^{13}$ The R\&D data in datastream (code 01201) captures firm expenditure and follows the Frascati Manual in including basic \& applied research; and development. It excludes contributions by government, customers, partnerships or other corporations to the company's research and development expense. Other Datastream data sources are for sales (01001); employees (07001); free cash flow (04201); taxes paid (01451); capital expenditure (04601); net profit before taxes (01401).
} 
expenditures are expensed and this reduces the overall tax paid, this variable is transformed as in Hall (1992) and (Malmberg 2008) into profit before allocations and tax, plus depreciation, minus tax, plus after tax R\&D expenditure.

Data for the corporate governance variables were obtained by purchased access to the Manifest global proxy governance and voting service database. Each of the components of the CG index as well as the ratios of share ownership by large blockholders. and by the CEO, were calculated from these data. Note the upward trend in the mean of the CG index over the sample period shown in Figure 3 that confirms that there has been significant variation in governance norms over the sample period in a way that allows panel data estimation to be applied. The period of our sample lies between the dot-com crash and the beginning of the global financial crisis, a period that was characterised by intense (exogenous) pressure for reform of corporate governance.

\section{RESULTS AND INTERPRETATION}

The results for Hypotheses $\mathrm{H} 1$ and $\mathrm{HA} 1$ are shown in Table 1, where the interaction term between governance and the cash flow term is excluded.. Results for $\mathrm{H} 2$ are in Table 2 where the interaction term is included. In both tables we report a standard fixed effects (FE) model, which however will suffer from biased coefficients given the short sample and the presence of a lagged dependent variable. The bias may be less serious on account of the low value of the coefficient on the lagged dependent variable and the presence of several other regressors; nevertheless it is appropriate to use alternative estimators for this case and we report the Arellano and Bond onestep robust GMM estimator. This is shown in the table as GMM. A further variant that uses additional instruments (in Table 2) is shown as GMM1. ${ }^{14}$

\section{[TABLE 1 HERE]}

\footnotetext{
14 The use of GMM is strictly required where the lagged dependent variable introduces Nickell bias (Arellano 2006). Nevertheless, the Fixed Effects results are useful for comparison and in the tables reported here, they give broadly similar results. The use of Random Effects models is ruled out because the sampling process is non-random. The GMM1 estimations augment the usual instrument set of lagged endogenous variables with industry averages for the endogenous variable CG to capture industry heterogeneity that may infleunce the firm CG observations (Cassiman and Veugelers 2002)
} 


\subsection{Hypotheses H1 and HA1}

Turning first to the first table, it may be seen that the basic R\&D model in the first two columns (excluding governance and cash flow variables) is validated with high overall significance and no problems with the diagnostics. In all cases, significance is found for the error-correction term in sales and a positive and stable dynamic effect is observed. The error-correction term is close to (minus) unity in the GMM estimates suggesting a rapid feedback to departure from target R\&D intensity. The coefficient on size is positive as expected and insignificant. The remaining columns report the effect of entering the governance variable and cash flow variables. The governance variable in levels is significantly negative in all specifications (FE and GMM) where time dummies are omitted, suggesting that there is a long-run negative effect of governance on R\&D. Thus there is no support for $\mathrm{H} 1$ but the contrary hypothesis HA1 is not rejected. This is consistent with the views of those who have argued that governance can have contradictory or perverse effects e.g. through reducing managerial security or discouraging the build-up of hard-to-measure real options (Palley 1997 Burkart et al 1997; Lazonick 2008; Hall and Lerner 2010; Van Pottelsberghe et al 2011). Thus, our interpretation here is that governance is shifting the demand for R\&D funds leftwards in Figure 1. We cannot rule out the possibility that the negative coefficients for the governance variable could represent an effect whereby firms are responding to empire-building tendencies in respect of R\&D. However, we have argued earlier that this is unlikely given the a-priori view that R\&D is characterised by underinvestment. Rather, we would interpret any effect here as in line with previous work such as (Baysinger et al 1991) who suggested that top executives " may be more willing to invest in risky R\&D projects if they...are less dependent on the judgement and evaluation of outside directors (p.211). To check for non-linearity we entered an additional quadratic term in CG without obtaining significance. Furthermore the Ramsey RESET test, executed for the fixed effects estimation in column (3) results in $F(3,288)=0.18$ and thus indicates no problem of mis-specification and in particular no problem due to non-linear functions of the variables being omitted.

Table 1 also reports estimates that include time dummies in columns (5) and (6). This is done to check for stability in the coefficients; such dummies with differenced 
equations imply shifts in growth rates. Our main interest here is in whether the equation coefficients are broadly stable. Most of them are, though the magnitude and significance of the $C G$ terms fall, probably reflecting co-movement of $C G$ across firms due to the compliance pressure exerted by investors over the sample period (Temple et al 2001). However, most of the time dummy terms are not individually significant and an exclusion test for them in shows only marginal significance for the whole set ( $P=0.041$ for coumn 5). Given that the Sargan test is acceptable at the $1 \%$ level and fails only marginally at the $5 \%$, and that there are no problems with autocorrelation, it is reasonable to regard the results without time dummies as acceptable (Arellano 2006).

A further test of robustness was carried out with a split sample. As with any panel of high technology firms, the question arises whether the boundary or nature of the firm can be regarded as stable given that technology will allow a shift in ownership and size and possibly product and process orientation. It is extremely difficult to deal with this but we approached it as follows. We obtained data on all deal activity affecting any of the firms in our sample, using the Zephyr database, excluding any small deals less than $£ 10 \mathrm{~m}$. We then combined data on acquisitions, disposals and mergers and normalised the total by each firms capital expenditure over the sample period.

Ranking the scaled index of deal activity, we selected the top 10\% (9 companies) which we proceeded to exclude from the sample on the grounds that they are the most unstable. The results confirmed those in table 1 , with broad similarity in results and with the $C G$ variables continuing to be significantly negative.

We also carried out a split sample estimation for firms that are defence related and likely to be in receipt of public subsidies which we identified as firms in the Aerospace, Electronic \& Electrical Equipment, and Fixed and Mobile telecommunication sectors. Excluding these 18 firms, we again obtained results very similar to those reported in Table 1, and here with even stronger significance than before for the CG terms.

\subsection{Hypothesis $\mathrm{H} 2$}

In the results for Table 1 we found no significant effects from cash flow, in line with other studies for large firms (Brown et al 2009), although the coefficients are always 
positive in line with expectation. We now report on Table 2 results where the role of corporate governance is seen as modifying the coefficient on the cash flow term in a new interaction effect.

\section{[TABLE 2 HERE]}

Table 2 results are somewhat similar to Table 1 in respect of the error correction term, which is again close to unity for the GMM estimates; the lagged dependent variable is also significant and not much different from the estimates in Table 1. We introduce an interaction term between the levels governance variable and the cash flow term, to test the argument that financial constraints are modified by governance. We find that the interaction term is negatively significant, implying that the cash flow effect (finance constraint) is eliminated for firms with more governance. The constraint is binding for a governance index less than approximately 1.6 which is just under a half of the mean for this variable. As with the results in Table 1, the terms in CG lose significance in the presence of time dummies, though the interaction term itself is strongly significant. To test the combined effects of the variables comprising the interaction term (with time dummies), we performed a chisquared exclusion test for column (6) that showed the terms to be jointly significant $(p=0.084)$.

Arguably, the result above could reflect the hypothesised effect of good governance on reducing agency costs of external finance. However, it is hard to square with the failure to find any direct positive role for governance. An alternative explanation is that an increased level of governance breaks any link between $R \& D$ intensity and cash flow by raising hurdle rates for $R \& D$ in favour of increased dividend pay-out ratios (Lazonick 2008; Driver and Temple 2010). This implies that the demand for R\&D finance falls as a result of board strategy, eliminating any constraint, though any improvement in the terms on which finance is available is irrelevant. Referring to Figure 1 the effect found here can be illustrated by increased governance causing a leftward shift of the demand for funds so that it intersects the horizontal portion of the supply curve where no finance constraint is binding. Our results here suggest qualified support for $\mathrm{H} 2$ but - given the lack of any positive CG effect - with a different interpretation to that implied by standard principal agency theory. 


\subsection{Disaggregated Results For Hypothesis $\mathrm{H3}$}

The principal-agent hypothesis conjectures that closer attention to firms' strategy and operations, occasioned by governance improvements should not only reassure investors but also take effect through the direct channel of better allocation of resources and better decision-making generally within the firm. Thus we investigate whether sub-indices of the overall governance variable $C G$ have positive effects for $R \& D$.

The governance results for $\mathrm{H} 3$ are shown in the first three columns of Table 3, based on disaggregating the overall $C G$ index. The first column shows the effect of using just the compensation component (termed CGX1). Here we find the directional influence is the same as for the total index, with significance obtained at the $10 \%$ level, The result implies that efforts to change managerial approaches by strong compensation incentives appear to result in reduced $R \& D$.

We also find perverse results for the board size variable (CGX2) in the second column where both the lag and the first difference term are significantly negative. Recalling that the variable here is a unit dummy for size less than 12 members, this implies that smaller size is actually detrimental to R\&D. The third column tests the combination of separate CEO and the Higgs director independence requirement (CGX3). Here again we find the same directional effect as in the overall index implying a negative effect (at $5 \%$ significance) on R\&D from the application of such procedures. $^{15}$

In Table 3, the coefficients of the basic variables from equation (1) are broadly stable in comparison to those in Table 1. The Sargan test for columns 1 and 3 indicates some mis-specification, though for the board size result it is acceptable at the $1 \%$ level. The mis-specification is not totally surprising given that we have no strong prior for the individual effects. The Sargan statistic is not improved by the addition of time dummies and although it is possible that various interaction effects or non-linearities could resolve the issue we leave this exercise for future work with larger samples. Overall, these results uniformly reject Hypothesis 3 that the sub-indices effects are

\footnotetext{
${ }^{15}$ Interestingly we did not find that these on their own were significant from which we conclude that it is compliance with the governance indices and codes that is driving the results.
} 
signed opposite to the main CG index. The results here are consistent with those observed in Van Pottelsberghe et al (2011) who observed a negative effect on R\&D intensity for performance related pay systems, as well as for the overall corporate governance score.

\subsection{Hypothesis H4: Ownership Effects}

In columns (4) to (6) of Table 3 we report the effect of including indicators of institutional and managerial (CEO) shareholdings.Column 4 gives the results for block ownership, where the argument that blocks exceeding $5 \%$ of holdings enable more efficient oversight of firms is assessed in relation to the effect on R\&D. Here we find a negative effect at the $10 \%$ level. It is of course true that this merely represents an average effect across quite varied types of block holding; a larger sample of firms would be needed to discriminate between various different types of block, or different types of institutional investor according to their mandate or their form of dealing .

Columns 5 and 6 of Table 3 deal specifically with managerial ownership and here there does appear to be a significant positive effect on R\&D. In these columns we use a $1 \%$ threshold for the ownership dummy variable because very few cases (only $8 \%$ ) exceed the $5 \%$ conventional threshold that is generally used for block ownership. To test the robustness of this link between R\&D intensity and CEO ownership, we replaced the dummy variable by the actual percentage owned by the CEO. Again it was significantly positive. Overall, the results in columns 5 and 6 are stable vis a vis those in Table 1 and the Sargan tests are acceptable. We did not find any non-linear effect for managerial ownership.

\section{[TABLE 3 HERE]}

\section{CONCLUSIONS}

Finance and governance are likely to influence $R \& D$ expenditure in complex ways and there is certainly no consensus in the literature as to the expected nature and strength of any effects. This paper has obtained a number of interesting results for the UK case. 
Our first result is that there is no evidence at all of a positive impact of governance on R\&D across any of the estimation SETS. Rather, there is evidence in favour of a negative effect of high levels of governance on R\&D, an outcome that contrasts with the perspective of "good governance", but which is quite in accordance with a longstanding literature that argues for the importance of managerial security and autonomy if risky investments are to be sustained.

There is no strong evidence for an unmediated effect of financial constraints on $R \& D$ in our sample. However, by introducing an interaction effect between governance and financial constraint we identify an effect whereby financial constraints are important but may be negated at high levels of governance. One obvious inference is to claim that governance is relaxing financial constraints through increased investor confidence. However this explanation is hard to square with the absence of a direct positive effect of the governance variable on $R \& D$. An alternative explanation is that stronger governance lowers finance constraints by imposing a higher hurdle for $R \& D$ investment and reducing the "demand " for R\&D by firms. Put differently firms operating under strong governance may ration $R \& D$ expenditure so as to increase disbursements such as dividends or to divert expenditure to faster payback projects (Lazonick 2008; 2010; Tylecote and Ramirez 2006). This would be consistent with the observed interaction effect and also with a failure to find any positive direct impact of governance on $R \& D$.

The results for the overall index represent the effects occurring through investor pressure for conformity. Individual components of the index may have particular effects that are positive for $R \& D$ even if the overall index is - as observed- negative for R\&D. In our disaggregated estimation we did not find any such positive effects within the index. Nor did we find that block ownership such as large institutional holdings increased R\&D but rather decreased it (at 10\% significance). We did, however, indentify one positive effect for R\&D occurring through CEO ownership. The higher this is, the more R\&D is performed. A positive R\&D effect is also observed when CEO ownership reaches a threshold of $1 \%$ of the total. This managerial ownership effect seems likely to reflect the influence of independence or autonomy of the (informed) CEO in relation to the board, in addition to any incentive effect from ownership. 
Statistics over firm-year observations

\begin{tabular}{|l|c|c|c|c|c|}
\hline Variable & $\underline{\text { Mean }}$ & $\underline{\text { Median }}$ & $\underline{\text { Minimum }}$ & $\underline{\text { Maximum }}$ & $\frac{\underline{\text { Standard }}}{\text { deviation }}$ \\
\hline R\&D (£ 000$)$ & 112,560 & 13,152 & 1,610 & $3,136,000$ & $385,769.1$ \\
\hline $\begin{array}{l}\text { R\&D intensity } \\
\text { (\%) }\end{array}$ & 8.31 & 4.05 & 0.08 & 198.08 & 16.81 \\
\hline Sales (£ 000$)$ & $4,093,082$ & 484,000 & 5,891 & $155,000,000$ & $14,500,000$ \\
\hline CF(£'000) & $619,172.1$ & $38,579.5$ & $-30,6000$ & $17,200,000$ & $1,925,337$ \\
\hline CG & 3.61 & 4 & 1 & 6 & 1.22 \\
\hline Employees & 19.980 & 4,461 & 47 & 295.000 & $40,379.79$ \\
\hline
\end{tabular}

\section{References}

Aghion, P., \& Tirole, J. 1997. Formal and real authority in organizations. Journal of Political Economy. 105 (1), 1-29.

Aghion, P., Bloom, N., Griffith, R., \& Howitt, P. 2005. Competition and innovation: an inverted U relationship. Quarterly Journal of Economics, 120, 701-728.

Aghion P., J Van Reenan and Zingales, L. 2009. Innovation and Institutional Ownership, NBER Working Paper 14769.

Aguilera, R. V. and G. Jackson. 2010. Comparative and International Corporate Governance. The Academy of Management Annals, 4 (1), 485 - 556.

Arellano, M. 2006. Panel Data Econometrics, Oxford OUP.

Asplund, M. 2000. What fraction of a capital investment is sunk costs? Journal of Industrial Economics, 48, 287-304.

Baysinger, B., Kosnik, R., \& Turk, T. 1991. Effects of board and ownership structure on corporate strategy. Academy of Management Journal, 34, 205-214.

Becker, B., \& Hall, S.G. 2009. Foreign direct investment in R\&D and exchange rate uncertainty. Open Economies Review , 20 (2), 207-223. 
Belloc, F. 2012. Corporate governance and innovation: a survey. Journal of Economic Surveys, doi: 10.1111/j.1467-6419.2011.00681.

BERR. 2008. Supporting Analysis for 'Manufacturing Strategy: New Challenges, New Opportunities. Department for Enterprise and Regulatory Reform, Economics Paper No.2.

Bertrand, M.\& Mullainathan, S. 2003. Enjoying the quiet life? Corporate governance and managerial preferences. Journal of Political Economy ,111, 1043-1075.

Birkinshaw J. 2001. Strategy and Management in MNE Subsidiaries" in Rugman , A.M. and Brewer, T.L. (2001) The Oxford Handbook of International Business, Oxford University Press.

Black, B., Jang, H., \& Kim, W. 2006. Does corporate governance predict firms' market values? Evidence from Korea. Journal of Law, Economics and Organization, 22, 366- 413.

Bloom,N., Griffith , R. \& A. Klemm. 2001. Issues in the deign and implementation of an R\&D tax credit for UK firms. IFS Briefing Note No. 15.

Bond, S., Harhoff, D., \& Reenen, J. V. 2003. Investment, R\&D and financial constraints in Britain and Germany. CEP Discussion Papers dp0595, Centre for Economic Performance, LSE.

Bond, S., \& Van Reenen, J. 2007. Microeconomic models of investment and employment. in: Heckman, J. and Leamer, E. (Eds), Handbook of Econometrics, vol. 6: 4417-4498. North-Holland, Amsterdam.

Brown, J. R., Fazzari, S. M., \& Petersen, B. C. 2009. Financing innovation and growth: Cash Flow, external equity, and the 1990s R\&D boom. Journal of Finance, 64 (1), 151-185.

Bruner, Christopher M. 2010. Power and Purpose in the 'Anglo-American' Corporation. Virginia Journal of International Law. 50 (3), Washington \& Lee Legal Studies Paper No. 2010-2.

Bulli, S. 2008. Business innovation investment in the UK. Science and Innovation Analysis, DIUS.

Burkart, M., Gromb, D., \& Panunzi, F. 1997. Large shareholders, monitoring, and the value of the firm. The Quarterly Journal of Economics, 112, 693-728.

Bushee, B. J. 1998. The influence of institutional investors on myopic R\&D investment behaviour. The Accounting Review, 73, 305-333.

Calderini M \& P. Garrone. 2003. Liberalization and the balance of R\&D activities: an empirical analysis. in Calderini M, P Garrone and M Sobrero (2003). Corporate Governance and Market Structure and Innovation, Edward Elgar. 
Canepa, A., \& Stoneman, P. 2008. Financial constraints to innovation in the UK: Evidence from CIS2 and CIS3. Oxford Economic Papers, 60 (4), 711-730.

Casper, S. 2009. Can new technology firms succeed in coordinated market economies? A response to Herrmann and Lange. Socioecomic Review, 7 (2), 209-215.

Cassiman B. \& R. Veugelers. 2002. R\&D Cooperation and Spillovers: Some Empirical Evidence from Belgium. American Economic Review, 92 (4), 1169-1184.

Cheng, S. 2004. R\&D expenditures and CEO compensation. The Accounting Review, 79, 305-28.

Cheng, S. 2008. Board size and the variability of corporate performace. Journal of Financial Economics, 87(1), 157-176.

Chirinko, R.S., \& Schaller, H. 2009. The irreversibility premium. Journal of Monetary Economics , 56 (3), 390-408.

Cincera, M \& Ravet, J. 2010. Financing constrains and R\&D investments of large corporations in Europe and the US. , Science and Public Policy, 37(6), 455-466.

Cohen, W. M., \& Levinthal, D. 1989. Innovation and learning: The two faces of R\&D. Economic Journal, Royal Economic Society, 99 (397), 569-596.

Cohen, W. M. 1995. Handbook of the Economics of Innovation and Technological Change, chapter: Empirical studies of innovative activity: 182-264. Blackwell.

Cohen, W. M., Nelson, R. R., \& Walsh J. P. 2000. Protecting their intellectual assets: Appropriability conditions and why U.S. manufacturing firms patent (or not), NBER Working Papers 7552, National Bureau of Economic Research, Inc.

Conyon, M.J. ,Fernandes, N., Ferreira, M. A., Matos, P. \& Murphy, K. J. 2009 The Executive Compensation Controversy:A Transatlantic Analysis presented at the Annual FRDB conference held in Cagliari (Italy) on the 29th May..

Coombs, R., Saviotti, P., \& Walsh, V. 1987. Economics and Technological Change. Rowmen and Littlefield NJ.

Crepon, B., Duguet, E., \& Mairesse, J. 1998. Research, innovation, and productivity: An econometric analysis at the firm level. Economics of Innovation and New Technology, 7(3), 115-156.

Crouch, C. \& Voelzkow, H. 2009. Innovation in Local Economies, OUP.

David, P., Hitt, M., \& Gimeno, J. 2001. The influences of activism by institutional investors on R\&D. Academy of Management Journal, 44, 144-157. 
Demirag, I.S. \& Doi. N. 2007. R\&D management under short term pressures: a comparative study of the UK and Japan. International Journal of Technology Management, 40(4), 249-277.

Devers, C. E., McNamara, G., Wiseman, R. M., \& Arrfelt, M. 2000. Moving closer to the action: Examining compensation design on firm risk, Organization Science, 19(4), 548-566.

Dixit A. and Pindyck R. 1993. Investment under Uncertainty. Harvester NY.

Driver, C. 2012. Governance, Innovation and Finance. in T Clarke and D Branson (eds) Sage Handbook of Corporate Goverance, Sage Publications.

Driver, C., Temple, P., \& Urga, G. 2005. Profitability, capacity and uncertainty: a model of UK manufacturing investment. Oxford Economic Papers, 57, 120-141.

Driver, C., Temple, P., \& Urga, G. 2008. Real options - delay vs. pre-emption: Do industrial characteristics matter? International Journal of Industrial Organization, 26, 532-545.

Driver, C., \& Temple, P. 2010. Why do hurdle rates differ from the cost of capital? Cambridge Journal of Economics; 34 (3), 501-523.

EIRMA. 2000. Centralized versus Decentralized R\&D: Benefits and Drawbacks. Working Group 56, EIRMA, France.

Eisenhardt, K. M. 1989. Agency theory: An assessment and review, Academy of Management Review, 14 (1), 57-74.

Eng, L. L., \& Shackell, M. 2001. The implications of long-term performance plans and institutional ownership for firm's research and development investment. Journal of Accounting, Auditing and Finance, 16, 117-139.

Frank, M. Z., \& Goyal, V. K. 2008. Trade off and pecking order theories of debt. In: Eckbo, E. (Ed), Handbook of corporate finance: Empirical corporate finance, Vol. 2, , Chapter 12, Elsevier.

García-Quevedo, J. 2004. Do Public Subsidies Complement Business R\&D? A Meta-Analysis of the Econometric Evidence. KYKLOS, 57(1), 87-102.

Ghosh, A., Moon, D. \& Tandon, K.. 2007. CEO ownership and discretionary investments. Journal of Business Finance Accounting, 34(5-6), 819-6-839.

Gompers, P. A., Ishii, J., \& Metrick, A. 2003. Corporate governance and equity prices. Quarterly Journal of Economics, 118, 107-155.

Gonzales,X. and Pazo,C. 2008. Do public subsidies stimulate private R\&D spending? Research Policy, 37, 371-389. 
Greenhalgh C. Rogers M. 2010. Innovation, Intellectual Property and Economic Growth, Princeton University Press.

Guest P.M. 2009. The Impact of Board Size on Firm Performance: Evidence from the UK. The European Journal of Finance, 15 (4, June), 85-404.

Guellec, D., \& Van Pottelsberghe de la Potterie, B.,2003. The Impact of Public R\&D Expenditure on Business R\&D. , Economics of Innovation and New Technology, $12(3)$, S. 225-243.

Hall, B. H. 1990. The impact of corporate restructuring on industrial research and development. Brookings papers on economic activity: Microeconomics, Washington, DC.

Hall, B.H. 1992. Investment and research and development at the firm level: Does the source of financing matter? NBER Working Papers 4096, National Bureau of Economic Research, Inc.

Hall, B. H. 2002. The Financing of Research and Development. Oxford Review of Economic Policy, Oxford University Press,18 (1), 35-51.

Hall, B. H., \& Lerner, J. 2010. The Financing of R\&D and Innovation, in Hall, B. H. and N. Rosenberg (Eds.), Handbook of the Economics of Innovation, Elsevier-North Holland.

Hall P. \& Soskice, D. 2001 Varieties of capitalism: the institutional foundations of comparative advantage., Oxford University Press.

Hancke, B. 2009. Debating Varieties of Capitalism: a reader, Oxford University Press.

Harhoff, D. 1998. Are there financing constraints for R\&D and investment in German manufacturing firms? Annales d'Economie et de Statistique, 49-50, 421-456.

Higgs, D. 2003. Review of the role and effectiveness of Non-Executive Directors, DTI London.

Hill, C., \& Snell, S. 1988. External control, corporate strategy and firm performance in research-intensive industries. Strategic Management Journal, 9, 577-590.

Himmelberg, C., \& Petersen, B. 1994. R\&D and internal finance: A panel study of small firms in high-tech industries. Review of Economics and Statistics, 76, 38-51.

Hubbard, R. G. 1998. Capital-Market Imperfections and Investment. Journal of Economic Literature, 36, 193-225.

Hughes, A. 2007. Innovation policy as cargo cult: myth and reality in knowledge-led productivity growth. CBR working paper 348, University of Cambridge. 
Hyytinen, A., \& Toivanen, O. 2005. Do financial constraints hold back innovation and growth? Evidence on the role of public policy. Research Policy, 34, 1385-1403.

Kafouros, M. I. 2005. R\&D and productivity growth: evidence from the UK. Economics of Innovation and New Technology., 14(6), 479-497.

Kor, Y. 2006. Direct and interaction effects of top management team and board compositions on R\&D investment strategy. Strategic Management Journal, 27(11), 1081-1099.

Krafft, J., \& Ravix, J-L. 2005. Corporate governance and the governance of knowledge: rethinking the relationship in terms of corporate coherence. Economics of Innovation and New Technology, 14(3-4), 1-25.

Kristensen, P.H. \& Zeitlin, J. 2005. Local Players in Global Games: the strategic constitution of a multinational corporation. Oxford University Press.

Lacetera, N. 2001. Corporate governance and the governance of innovation: the case of the pharmaceutical industry. Journal of Management and Governance, 5, 29-59.

Lang, G. 2009. Measuring the returns of R\&D - an empirical study of the German manufacturing sector over 45 years. Research Policy, 38(9), 1438-1455.

Lazonick, W. 2008. The quest for shareholder value: stock repurchases in the US economy. Recherches économiques de Louvain, 74(4), 479-540.

Lazonick, W. 2010. The Chandlerian corporation and the theory of innovative enterprise. Industrial and Corporate Change, 19(2), 317-349.

Lee, P.M..\& O'Neill, H. M. 2003. Ownership structures and R\&D investments of US and Japanese Firms: agency and stewardship perspectives. Academy of Management Journal 46(2), 212-25.

Lerner, J., \& Wulf, J. 2006. Innovation and Incentives: evidence from corporate R\&D. NBER paper 11944.

Lhuillery, S. 2011. The impact of corporate governance practices on R\&D efforts: a look at shareholders' rights, cross-listing and control pyramid. Industrial and Corporate Change, forthcoming. .

Love, J. H., \& Roper, S. 2001. Location and network effects on innovation success: evidence for UK, German and Irish manufacturing plants. Research Policy, 30, 643661.

Lundvall, B. 2002. Innovation, Growth and Social Cohesion,: the Danish model, Cheltenham. Edward Elgar. 
Lysandrou, P. \& Parker, D. 2011. Commercial corporate governance ratings: an alternative view of their use and impact, International Review of Applied Economics, DOI:10.1080/02692171.2011.619971.

Malmberg, C. 2008. R\&D and financial systems: The determinants of R\&D expenditures in the Swedish pharmaceutical industry. CIRCLE Electronic Working Paper Series, WP 2008/01, Lund University.

Mallin, C. 2007. Corporate Governance, 2nd edn Oxford OUP.

Mairesse, J., Hall, B. H., \& Mulkay, B. 1999. Firm-level investment in France and the United States: An exploration of what we have learned in twenty years, Working Paper 7437, National Bureau of Economic Research.

McDonald, R. L. 1998. Real options and rules of thumb in capital budgeting. In: Brennan, M.J., Trigeorgis, L. (Eds.), Innovation, Infrastructure, and Strategic Options. Oxford University Press, London.

Moncada-Paternò-Castello, P., Ciupagea, C., Smith, K. Tübke A. \& Tubbs, M. 2010. Does Europe perform too little corporate R\&D? A comparison of EU and nonEU corporate R\&D performance. Research Policy, 39(4), 523-536.

Munari, F \& Sobrero, M. 2003. Corporate governance and innovation. Chapter 1 in Calderini M., P. Garrone and M. Sobrero (2003) Corporate Governance and Market Structure and Innovation, Edward Elgar.

Munari, F., Oriani, R. \& Sobrero, M. 2010. The effects of owner identity and external governance systems on R\&D investments: a study of Western European firms. Research Policy, 39, 1093-1104.

OECD. 2004. OECD Principles of Corporate Governance, Organisation for Economic Cooperation and Development, Paris.

O'Mahony. M. \& Vecchi, M. 2009. R\&D, knowledge spillovers and company productivity performance. Research Policy, 38, 35-44.

O'Sullivan, M. 2005. Finance and Innovation, Chapter 9 in Fagerberg, J. , Mowery, D. C., \& Nelson, R. R. (Eds.), The Oxford Handbook of Innovation, Oxford University Press.

Palley ,T. I. 1997. Managerial turnover and the theory of short-termism. Journal of Economic Behavior and Organization ,32(4), 547-557.

Pavitt, K. 2005. Innovation processes. In: Fagerberg, J., Mowery, D.C, \& Nelson, R. R. (Eds.), The Oxford Handbook of Innovation; Oxford University Press.

Porter, M. E. 1985. Technology and competitive advantage. Journal of Business Strategy, 5(3), 60-77. 
Reichstein T., \& Salter A. 2006. Investigating the sources of process innovation among UK manufacturing firms. Industrial and Corporate Change, 15(4), 653-682.

Rogers, M. 2006. R\&D and productivity in the UK: Evidence from firm-level data in the 1990s, Economics Series Working Papers 255, University of Oxford, Department of Economics.

Roper, S., Du, J., \& Love, J. H. 2008. Modelling the innovation value chain. Research Policy, 37, 961-977.

Saviotti, P. 1987. Research and development in the firm: Strategy and structure" in Coombs, R., Saviotti P., \& Walsh V. Economics and Technological Change, New Jersey, Rowmen and Littlefield.

Smit, H., \& Trigeorgis, L. 2004. Strategic Investment, Real Options and Games, Princeton, Princeton University Press.

Smith V., Madsen, E. S., \& Dilling-Hansen, M. 2001. Investment in R\&D and corporate governance. Quartlerly Journal of Economic Research , 263-73.

Stephan, A. 2004. R\&D expenditure of firms over the business cycle: Evidence for Germany. Study for the German Ministry of Education and Science. ZEW Mannheim, IFO München, DIW Berlin, Stifterverband Essen Workshop of the NIESR London.

Stein, J. C. 2003. Agency, information and corporate investment, in Constantinides, G. M., Harris, M., \& R. M. Stultz, R. M. (Eds.), Handbook of the Economics of Finance, Vol. 1A Corporate Finance, Elevier.

Summers, L. 1981. Taxation and corporate investment: A Q theory approach, Brookings Papers on Economic Activity, 1/1981, 67-140.

Taylor, M. Z. 2004. Empirical evidence against varieties of capitalism's theory of technological innovation. International Organization, 58, 601-631.

Temple, P., Urga, G., \& Driver, C. 2001. The influence of uncertainty on fixed investment in the UK: a macro or a micro phenomenon. Scottish Journal of Political Economy, 48(4), 361-821.

Tirole, J. 2006. The Theory of Corporate Finance, Princeton University Press.

Tylecote, A. 2007. The role of finance and corporate governance in national systems of innovation. Organization Studies, 28 (10), 1461-1481.

Tylecote, A. \& Ramirez, P. 2006. Corporate governance: the UK compared with the US and "insider" economies. Research Policy , 35(1), 160-180.

Tylecote, A. \& Visintin, F. 2008. Corporate Governance, Finance and the Technological Advantage of Nations, Routledge. 
Ughetto, E. 2008. Does internal finance matter for R\&D: New evidence from a panel of Italian firms. Cambridge Journal of Economics, 32(6), 907-25.

Van Pottelsberghe, B., Honore, F. and Munari, F. 2011. Corporate governance practices and companies' R\&D orientation: Evidence from European countries. Bruegel Working Paper 2011/01, 24 January 2011

Vecchi, M., Barrel, R., Becker, B., Schmidt-Ehmcke, J., \& Stephan, A. 2007. The determinants of investment in industrial research and development in the United Kingdom and in Germany: Final research report to the Anglo-German foundation, National Institute of Economic and Social Research and German Institute for Economic Research.

Wakelin, K., 2001. Productivity Growth and R\&D Expenditure in UK Manufacturing Firms. Research Policy, 30, 1079-1090.

Windsor, D. 2009. Tightening corporate governance. Journal of International Management , 15, 306-316.

Wu, J., \& TU, R. 2007. CEO stock option pay and R\&D spending: A behavioral agency explanation. Journal of Business Research, 60, 482-492.

Yermack, D., 1996. Higher Market Valuation of Companies with a Small Board of Directors. Journal of Financial Economics, 40: 185-211. 
FIGURE 1 POSSIBLE EFFECTS OF GOVERNANCE ON CASH FLOW TERM DUE TO INDUCED EFFECTS ON DEMAND FOR FUNDS AND SUPPLY OF EXTERNAL FUNDS

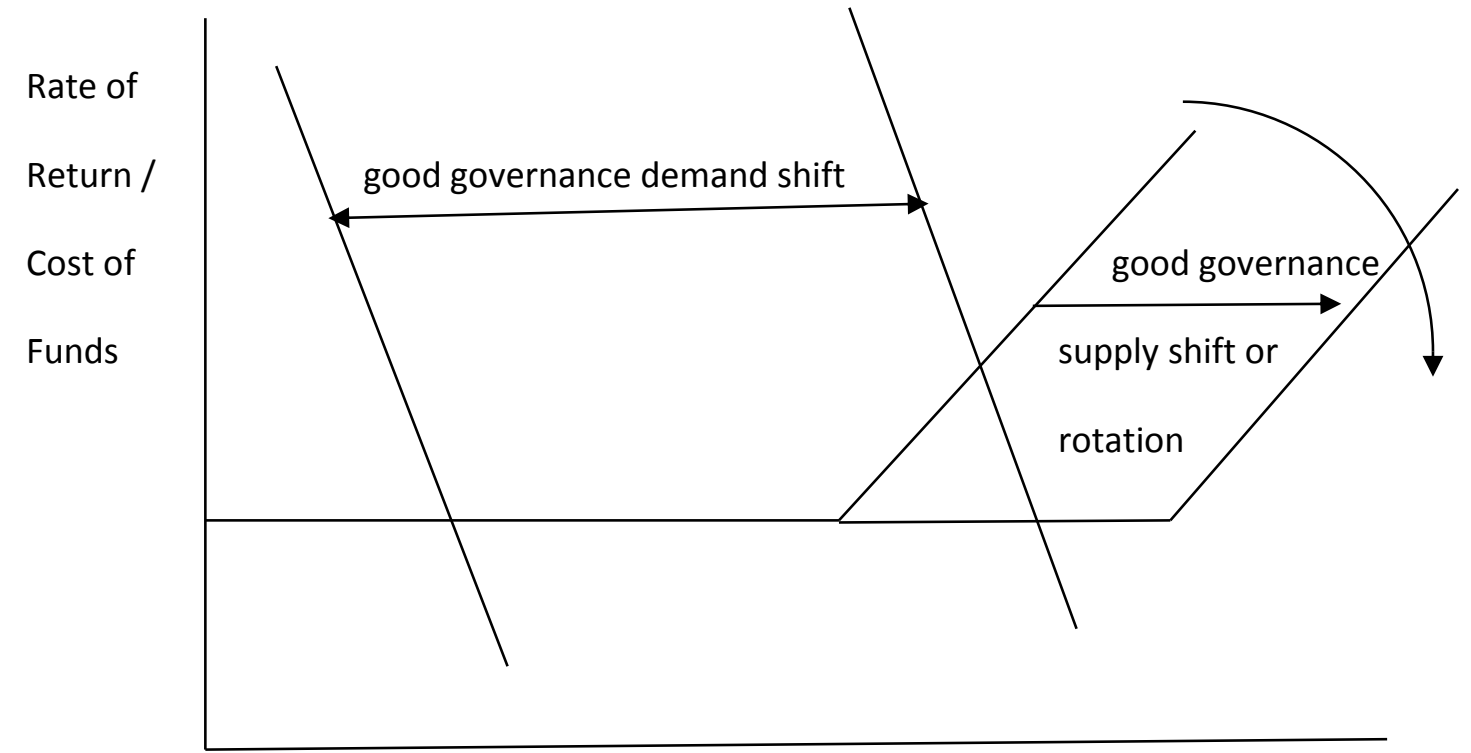

Adapted from Hubbard 1998

R\&D investment 
Figure 2 R\&D Intensity

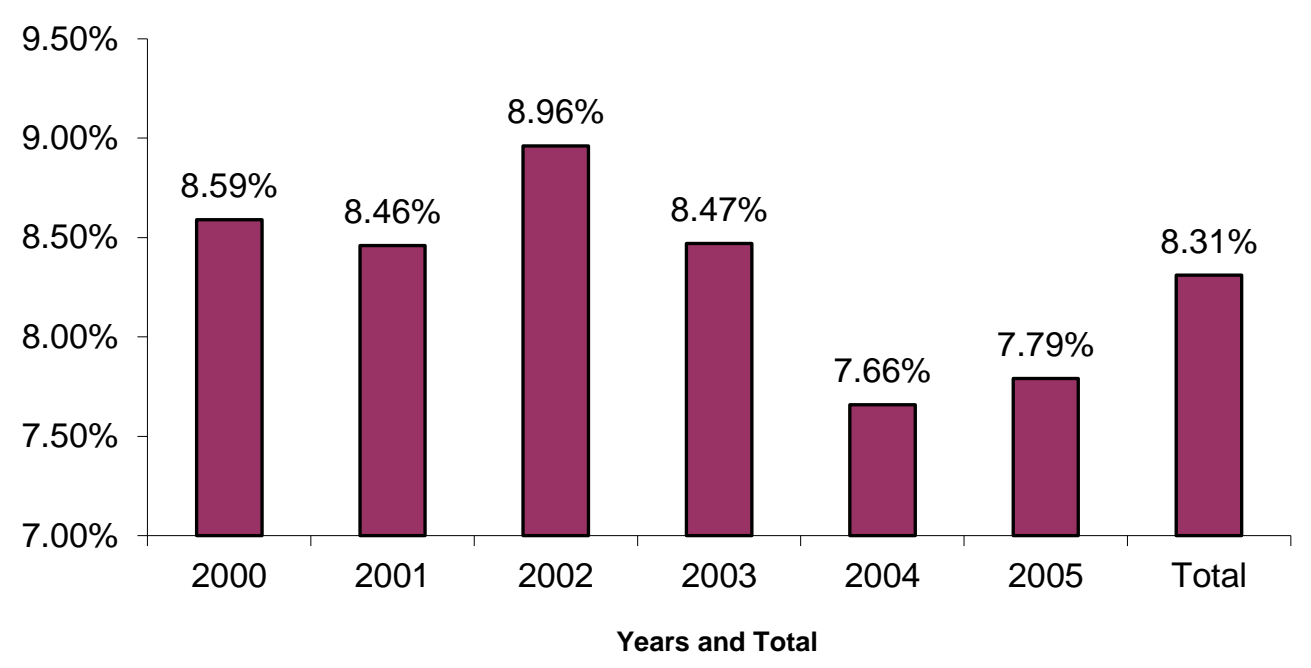

Figure 3 Corporate Governance Index

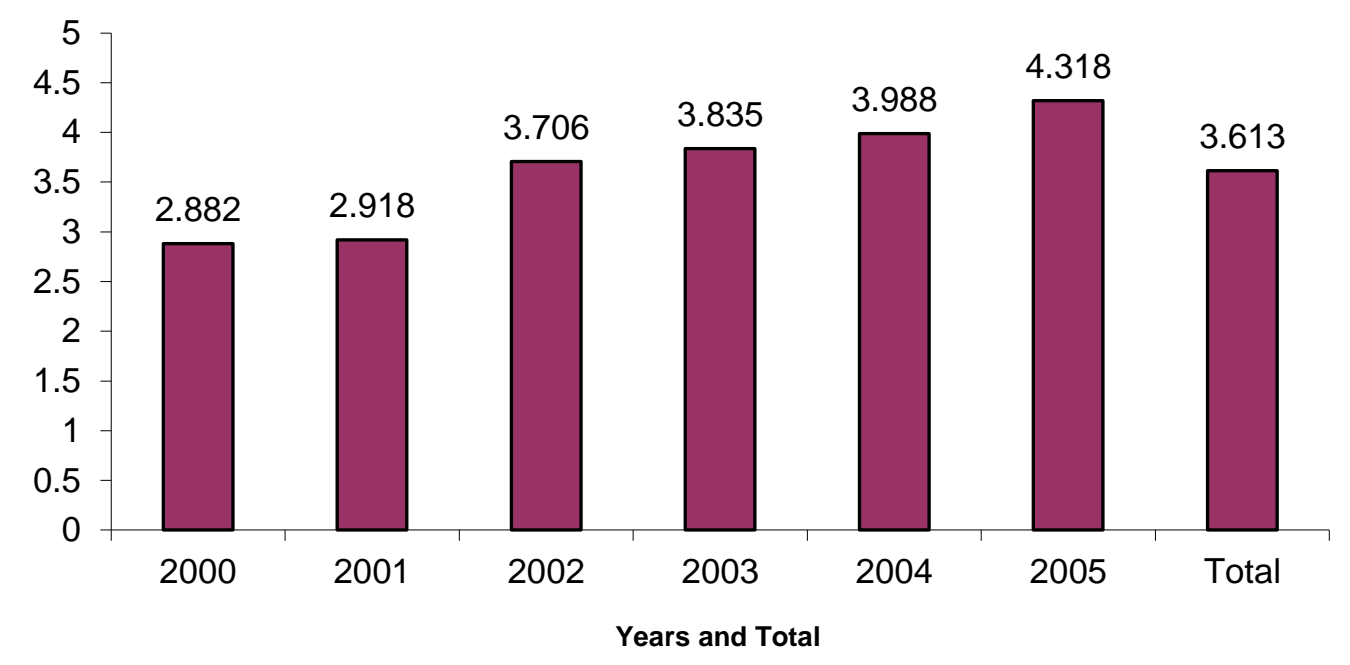


Table 1 Dependent Variable $\Delta \ln (R D I)_{t} *$

\begin{tabular}{|c|c|c|c|c|c|c|}
\hline & (1) FE & (2) GMM & (3) $\mathrm{FE}$ & (4) GMM & (5) FE & (6) GMM \\
\hline Constant & $\begin{array}{c}-2.7901^{* * *} \\
(0.9557)\end{array}$ & $\begin{array}{c}-4.1291^{* * *} \\
(0.8854)\end{array}$ & $\begin{array}{c}-3.4435^{* * *} \\
(1.0361)\end{array}$ & $\begin{array}{c}-3.9962^{* * *} \\
(1.0210)\end{array}$ & $\begin{array}{c}-3.8574^{* * *} \\
(0.9462)\end{array}$ & $\begin{array}{c}-4.6374 * * * \\
(0.9064)\end{array}$ \\
\hline$\Delta \ln (R D I)_{i, t-1}$ & $\begin{array}{c}0.2781^{* *} \\
(0.1216)\end{array}$ & $\begin{array}{c}0.1718 \\
(0.1363)\end{array}$ & $\begin{array}{l}0.2622^{*} \\
(0.1376)\end{array}$ & $\begin{array}{c}0.1767 \\
(0.1538)\end{array}$ & $\begin{array}{c}0.2554^{*} \\
(0.1526)\end{array}$ & $\begin{array}{c}0.1606 \\
(0.1743)\end{array}$ \\
\hline $\ln (R D I)_{i, t-1}$ & $\begin{array}{c}-0.8070^{* * *} \\
(0.1882)\end{array}$ & $\begin{array}{c}-0.9863^{* * *} \\
(0.1457)\end{array}$ & $\begin{array}{c}-0.7779 * * * \\
(0.1931)\end{array}$ & $\begin{array}{c}-0.9737^{* * *} \\
(0.1838)\end{array}$ & $\begin{array}{c}-0.7719 * * * \\
(0.1987)\end{array}$ & $\begin{array}{c}-0.9625^{* * *} \\
(0.1902)\end{array}$ \\
\hline $\ln (S Z)_{i, t}$ & $\begin{array}{c}0.0036 \\
(0.0872)\end{array}$ & $\begin{array}{c}0.0897 \\
(0.1004)\end{array}$ & $\begin{array}{c}-0.0126 \\
(0.1052)\end{array}$ & $\begin{array}{c}0.0774 \\
(0.1029)\end{array}$ & $\begin{array}{c}0.0161 \\
(0.1022)\end{array}$ & $\begin{array}{c}0.1243 \\
(0.1016)\end{array}$ \\
\hline$\Delta C G_{i, t}$ & & & $\begin{array}{l}-0.0378 \\
(0.0232)\end{array}$ & $\begin{array}{l}-0.0421^{*} \\
(0.0246)\end{array}$ & $\begin{array}{l}-0.0205 \\
(0.0218)\end{array}$ & $\begin{array}{c}-0.0158 \\
(0.0193)\end{array}$ \\
\hline$C G_{i, t-1}$ & & & $\begin{array}{l}-0.0575^{*} \\
(0.0328)\end{array}$ & $\begin{array}{c}-0.0778^{* *} \\
(0.0381)\end{array}$ & $\begin{array}{l}-0.0269 \\
(0.0337)\end{array}$ & $\begin{array}{l}-0.0336 \\
(0.0359)\end{array}$ \\
\hline$\Delta \ln (C F)_{i, t-1}$ & & & $\begin{array}{c}0.0929 \\
(0.0616)\end{array}$ & $\begin{array}{c}0.0215 \\
(0.0400)\end{array}$ & $\begin{array}{c}0.0948 \\
(0.0629)\end{array}$ & $\begin{array}{c}0.0249 \\
(0.04039)\end{array}$ \\
\hline Time Dummies & No & No & No & No & Yes & Yes \\
\hline No Obs & 323 & 237 & 298 & 216 & 298 & \\
\hline Wald & & $(0.0000)$ & & $(0.0000)$ & & $(0.0000)$ \\
\hline Sargan & & $(0.4738)$ & & $(0.0428)$ & & $(0.7251)$ \\
\hline$A R(1)$ & & $(0.8932)$ & & $(0.4435)$ & & $(0.6891)$ \\
\hline$A R(2)$ & & $(0.6207)$ & & $(0.4470)$ & & $(0.6034)$ \\
\hline
\end{tabular}

* Estimation was carried out on STATA10 using the command XTREG for FE and XTABOND for GMM. Robust estimates are reported. Standard errors are in parentheses. One star signifies significance at the $10 \%$ level; two stars at $5 \%$ and three stars at $1 \%$. Wald is the $p$ value for the overall test of significance. AR1 and AR2 are the p-values for the Arellano-Bond tests for first and second order autocorrelation. Sargan is the $p$-value for the test of the independence of the instruments. 
Table 2 Dependent Variable $\Delta \ln (R D I)_{t}$

\begin{tabular}{|c|c|c|c|c|c|c|}
\hline & (1) $\mathrm{FE}$ & (2) GMM & (3) GMM1 & (4) $\mathrm{FE}$ & (5) GMM & (6)GMM1 \\
\hline Constant & $\begin{array}{c}-2.8961^{* * *} \\
(0.9984)\end{array}$ & $\begin{array}{c}-3.9575^{* * *} \\
(1.0199)\end{array}$ & $\begin{array}{c}-3.9488^{* * *} \\
(0.9791)\end{array}$ & $\begin{array}{c}-3.2288^{* * *} \\
(0.9273)\end{array}$ & $\begin{array}{c}-4.4640 * * * \\
(0.8532)\end{array}$ & $\begin{array}{c}-4.4520^{* * *} \\
(0.8663)\end{array}$ \\
\hline$\Delta \ln (R D I)_{i, t-1}$ & $\begin{array}{l}0.2155^{*} \\
(0.1257)\end{array}$ & $\begin{array}{c}0.1488 \\
(0.1434)\end{array}$ & $\begin{array}{c}0.1485 \\
(0.1423)\end{array}$ & $\begin{array}{c}0.2140 \\
(0.1375)\end{array}$ & $\begin{array}{c}0.1395 \\
(0.1621)\end{array}$ & $\begin{array}{c}0.1404 \\
(0.1613)\end{array}$ \\
\hline $\ln (R D I)_{i, t-1}$ & $\begin{array}{c}-0.7834^{* * *} \\
(0.1912)\end{array}$ & $\begin{array}{c}-0.9734^{* * *} \\
(0.1753)\end{array}$ & $\begin{array}{c}-0.9730 * * * \\
(0.1735)\end{array}$ & $\begin{array}{c}-0.7808 * * * \\
(0.1980)\end{array}$ & $\begin{array}{c}-0.9681^{* * *} \\
(0.1827)\end{array}$ & $\begin{array}{c}-0.9705^{* * *} \\
(0.1804)\end{array}$ \\
\hline $\ln (S Z)_{i, t}$ & $\begin{array}{c}0.0425 \\
(0.0867)\end{array}$ & $\begin{array}{c}0.1015 \\
(0.0986)\end{array}$ & $\begin{array}{c}0.1009 \\
(0.0976)\end{array}$ & $\begin{array}{c}0.0725 \\
(0.0852)\end{array}$ & $\begin{array}{c}0.1478 \\
(0.1016)\end{array}$ & $\begin{array}{l}(0.1449) \\
(0.1033)\end{array}$ \\
\hline$\Delta C G_{i, t}$ & $\begin{array}{l}-0.0376 \\
(0.0226)\end{array}$ & $\begin{array}{c}-0.0466^{*} \\
(0.0243)\end{array}$ & $\begin{array}{c}-0.0471^{* *} \\
(0.0223)\end{array}$ & $\begin{array}{l}-0.0220 \\
(0.0216)\end{array}$ & $\begin{array}{l}-0.0233 \\
(0.0193)\end{array}$ & $\begin{array}{l}-0.0223 \\
(0.0186)\end{array}$ \\
\hline$C G_{i, t-1}$ & $\begin{array}{l}-0.0489 \\
(0.0339)\end{array}$ & $\begin{array}{c}-0.0773^{* *} \\
(0.0373)\end{array}$ & $\begin{array}{c}-0.0778^{* *} \\
(0.0357)\end{array}$ & $\begin{array}{l}-0.0221 \\
(0.0363)\end{array}$ & $\begin{array}{l}-0.0399 \\
(0.0356)\end{array}$ & $\begin{array}{c}-0.0387 \\
(0.0355)\end{array}$ \\
\hline$\Delta \ln (C F)_{i, t-1}$ & $\begin{array}{c}0.0750^{* *} \\
(0.0331)\end{array}$ & $\begin{array}{c}0.0700 * * * \\
(0.0241)\end{array}$ & $\begin{array}{c}0.0699 * * * \\
(0.0243)\end{array}$ & $\begin{array}{c}0.0641^{* *} \\
(0.0301)\end{array}$ & $\begin{array}{c}0.0573^{* *} \\
(0.0227)\end{array}$ & $\begin{array}{c}0.0571^{* *} \\
(0.0225)\end{array}$ \\
\hline$\Delta \ln (C F)_{i, t-1} * C G_{i, t}$ & $\begin{array}{c}-0.0468^{* *} \\
(0.0203)\end{array}$ & $\begin{array}{c}-0.0346^{* *} \\
(0.0148)\end{array}$ & $\begin{array}{c}-0.0345^{* *} \\
(0.0149)\end{array}$ & $\begin{array}{c}-0.0412^{* *} \\
(0.0202)\end{array}$ & $\begin{array}{c}-0.0280 * * \\
(0.0143)\end{array}$ & $\begin{array}{c}-0.0280 * * \\
(0.0143)\end{array}$ \\
\hline Time Dummies & NO & NO & NO & YES & YES & YES \\
\hline No Obs & 293 & 212 & 210 & 290 & 212 & 212 \\
\hline Wald & & $(0.0000)$ & $(0.0000)$ & & $(0.0000)$ & $(0.0000)$ \\
\hline Sargan & & $(0.1148)$ & $(0.1526)$ & & $(0.7237)$ & $(0.7731)$ \\
\hline$A R(1)$ & & $(0.3317)$ & $(0.3340)$ & & $(0.6029)$ & $(0.6125)$ \\
\hline $\operatorname{AR}(2)$ & & $(0.7340)$ & (0.7331) & & (0.9233) & (0.9262) \\
\hline
\end{tabular}

See Notes to Table 1. GMM1 includes lagged value of the industry mean levels governance variable as additional instruments. 
Table 3 Dependent Variable $\Delta \ln (R D I)_{t} *$

\begin{tabular}{|r|c|c|c|c|c|c|}
\hline & $(1) \mathrm{GMM}$ & $(2) \mathrm{GMM}$ & $(3) \mathrm{GMM}$ & $(4) \mathrm{GMM}$ & $(5) \mathrm{GMM}$ & $(6) \mathrm{GMM}$ \\
\hline Constant & $-4.1478^{* * *}$ & $-3.5139^{* * *}$ & $-3.7412^{* * *}$ & $-3.8116^{* * *}$ & $-4.2801^{* * *}$ & $-4.5234^{* * *}$ \\
& $(0.9929)$ & $(0.9885)$ & $(1.0665)$ & $(1.1039)$ & $(0.9890)$ & $(0.9882)$ \\
\hline$\Delta \ln (R D I)_{i, t-1}$ & 0.2026 & 0.1924 & 0.2019 & 0.1884 & 0.1678 & 0.1839 \\
& $(0.1408)$ & $(0.1455)$ & $(0.1444)$ & $(0.1722)$ & $(0.1602)$ & $(0.1590)$ \\
\hline $\ln (R D I)_{i, t-1}$ & $-0.9699^{* * *}$ & $-0.9878^{* * *}$ & $-0.9828^{* * *}$ & $-1.0342^{* * *}$ & $-0.9826^{* * *}$ & $-0.9832^{* * *}$ \\
& $(0.1712)$ & $(0.1639)$ & $(0.1673)$ & $(0.1967)$ & $(0.1730)$ & $(0.1701)$ \\
\hline $\ln (S Z)_{i, t}$ & 0.0731 & 0.0066 & 0.0567 & -0.0236 & 0.0627 & 0.0954 \\
& $(0.1066)$ & $(0.1037)$ & $(0.1256)$ & $(0.1264)$ & $(0.1067)$ & $(0.1078)$ \\
\hline$\Delta C G X_{i, t}$ & $-0.1219^{*}$ & $-0.0966^{*}$ & 0.0078 & -0.1749 & $0.3120^{* * *}$ & -1.3889 \\
& $(0.0667)$ & $(0.0543)$ & $(0.0302)$ & $(0.1993)$ & $(0.0952)$ & $(1.4804)$ \\
\hline$C G X_{i, t-1}$ & $-0.1432^{*}$ & $-0.2046^{* *}$ & $-0.1176^{* *}$ & $-0.4626^{*}$ & $0.3067^{* *}$ & $2.8031^{* *}$ \\
& $(0.0758)$ & $(0.0974)$ & $(0.0566)$ & $(0.2707)$ & $(0.1197)$ & $(1.4143)$ \\
\hline$\Delta \ln (C F)_{i, t-1}$ & 0.0232 & 0.0185 & 0.0043 & 0.0480 & 0.0242 & 0.0200 \\
& $(0.0392)$ & $(0.0331)$ & $(0.0334)$ & $(0.0508)$ & $(0.0366)$ & $(0.0372)$ \\
\hline & & & & & & \\
\hline No Obs & 216 & 221 & 221 & 190 & 216 & 216 \\
\hline Wald & $(0.0000)$ & $(0.0000)$ & $(0.0000)$ & $(0.0000)$ & $(0.0000)$ & $(0.0000)$ \\
\hline Sargan & $(0.0000)$ & $(0.0151)$ & $(0.0004)$ & $(0.0959)$ & $(0.8427)$ & $(0.6661)$ \\
\hline AR(1) & $(0.2706)$ & $(0.4821)$ & $(0.1391)$ & $(0.6086)$ & $(0.6124)$ & $(0.4890)$ \\
\hline AR(2) & $(0.7507)$ & $(0.6462)$ & $(0.4910)$ & $(0.2042)$ & $(0.5236)$ & $(0.5777)$ \\
\hline
\end{tabular}

*See Notes to Tables 1.

Each column (1) to (6) has CGX(.) defined differently where the column number is (,).

In terms of the definitions in Section 4.2.:

CGX1 is the sum of the Bonus and Stock \& Option dummies

CGX2 is the dummy variable Board size

CGX3 is the sum of Observance of Higgs and Separation of Powers dummies

The ownership variables are as follows:

CGX4 is defined as a dummy $=1$ for existence of at least one shareholder with

ownership $>5 \%$ of the total.

CGX5 is defined as a dummy $=1$ for CEO share ownership > $1 \%$

CGX6 is defined as the actual \% CEO share ownership /100 
Acknowledgements

The corresponding author would like to thank the Research School of Social Sciences, Australian National University for research facilities during the writing of this paper. Maria João Guedes wishes to thank Fundação para a Ciência e Tecnologia, FCT, Portugal. We are also grateful to participants at the $8^{\text {th }}$ International Conference on Corporate Governance, University of Birmingham, May 2010; a presentation at the University of London (SOAS) May 2010; and at the ENEF annual conference, Amsterdam September 2010. Thanks also to Bettina Becker, Alex Coad, Paul Temple and Ammon Salter for comments on an earlier draft. Special thanks go to two referees for extensive and important comments which helped to improve the paper greatly. 